Chapter 6

\title{
Foreland Basins at the Miocene Arc-Arc Junction, Central Hokkaido, Northern Japan
}

\author{
Gentaro Kawakami \\ Additional information is available at the end of the chapter \\ http://dx.doi.org/10.5772/56748
}

\section{Introduction}

A foreland basin can be defined as a linear depression formed from the flexure of foreland lithosphere under the load of an orogenic wedge. Various factors control the basin geometry and the stratigraphic architecture of the basin fill [1].

During the Miocene age, a series of foreland basins were formed in Hokkaido, the northern island of Japan, due to an arc-arc collision event [2-4]. The basin area has a total length of 400 $\mathrm{km}$, and it is characterized by several rows of deep depressions stretched in a north-south direction and separated by topographic highs (Figure 1). The degree of total crustal shortening and exhumation by the collision event is larger in the southern region of the collision zone [5], and thus, the basin geometry and the stratigraphic/sedimentologic architecture of the basin fills vary among the depressions. Namely, the depression in the southern region has suffered progressive deformation due to thrust propagation, and the depocenter has migrated forelandward, a feature noted in many foreland basins [1]. In contrast, the depression in the northern region shows restrictive deformation and foreland-ward migration of depocenter. Thus, the initial geometry and stratigraphic architecture of the basin fill are well preserved even in the proximal margin of the basin. On the other hand, unlike the northern and southern regions, the depression located near the center of the foreland basin area has been affected by the existence of a projection on the foreland lithosphere. As a result, the depression shows very narrow basin geometry and restrictive foreland-ward migration of the depocenter.

Such spatial variations are caused mainly by regional differences in the degree of tectonic disturbance, as there is no radical difference in the geodynamic states of the underlying lithosphere throughout the foreland area. Considering the above factors, this study focuses on how the difference in the degree of tectonic deformation affects the foreland basin geometry, basin-filling process, and the resultant stratigraphy in a geological record. This paper firstly 
reviews the stratigraphic architecture and depositional system in each depression, and then discusses the relationship between basin evolution and tectonics.

\section{Geological setting}

The present Hokkaido Island is located on a junction between the Northeast Japan Arc and the Chishima (Kuril) Arc (Figure 1), which originated from an interaction between the Eurasian and Okhotsk plates that commenced in the Late Eocene [4]. A right-lateral oblique collision between the two arcs during the Miocene age formed a west-vergent fold-thrust belt and a subsiding foreland area nearly $400 \mathrm{~km}$ long in central Hokkaido [4].

Because of the right-lateral oblique collision and the subsequent westward migration of the Chishima forearc sliver [4], the collision event has endured longer in the south. In the northern region, the thrust activity had declined by the late Miocene, but in the southern region, it continues up untill the present-day. Therefore, the degree of total crustal shortening and exhumation by the collision event is larger in the southern region [5]. For instance, the amount of crustal shortening in the Sorachi-Yezo Belt varies from $12 \mathrm{~km}$ in the north, to $50-64 \mathrm{~km}$ in the south $[5,6]$.

An exhumed basement in the eastern orogen (the eastern zone of the Sorachi-Yezo Belt and the Hidaka Belt) consists of Cretaceous to Early Paleogene accretionary complexes (Figure 1) formed by the arc-trench system along the eastern margin of the Eurasian continent [7]. A metamorphic core of granulite facies crops out only in the southern area of the orogen (the Hidaka metamorphic rocks) [8]. The cooling ages of the metamorphic core indicate the middle to late Miocene ages (20-10 Ma), and are synchronized with the evolution of the foreland basin ([9] and references therein).

Before the foreland basin subsidence, relatively shallow sea environments were widespread in the area during the Early to early-Middle Miocene ages corresponding roughly to the sealevel rise during the Mid-Neogene Climatic Optimum [10]. However, the detailed tectonic control of this shallow marine basin remains unclear. It is evident that initial deep depressions were formed around 15-16 Ma, due to rapid subsidence (Figure 2). On close inspection, the central part of the foreland basin area is constricted, and this is probably owing to the existence of a projection on the foreland lithosphere (the Kabato basement high (KBH) of Rebun-Kabato Belt in Figure 1). The Rebun-Kabato Belt is defined by the Cretaceous arc volcanics/plutonics and forearc basin-fills [11] which are overlain by the thick sedimentary succession of Paleogene-Quaternary in the Ishikari Lowland.

Slightly right-stepping deep depressions developed in both the northern and southern parts of the foreland basin area. These deep depressions, known as the Tenpoku, Haboro, Ishikari, and Hidaka basins (from north to south) [3, 12] (Figure 1), are filled with Miocene-Pliocene deposits up to $6000 \mathrm{~m}$ thick (Figure 2), sourced from the eastern orogen [9, 12-16]. Most of the basin fills consist of parallel-sided, non-channelized turbiditic sand and basin-plain mud interbeds ("basinal turbidites": [17]) and coarser-grained turbiditic deposits of immature 


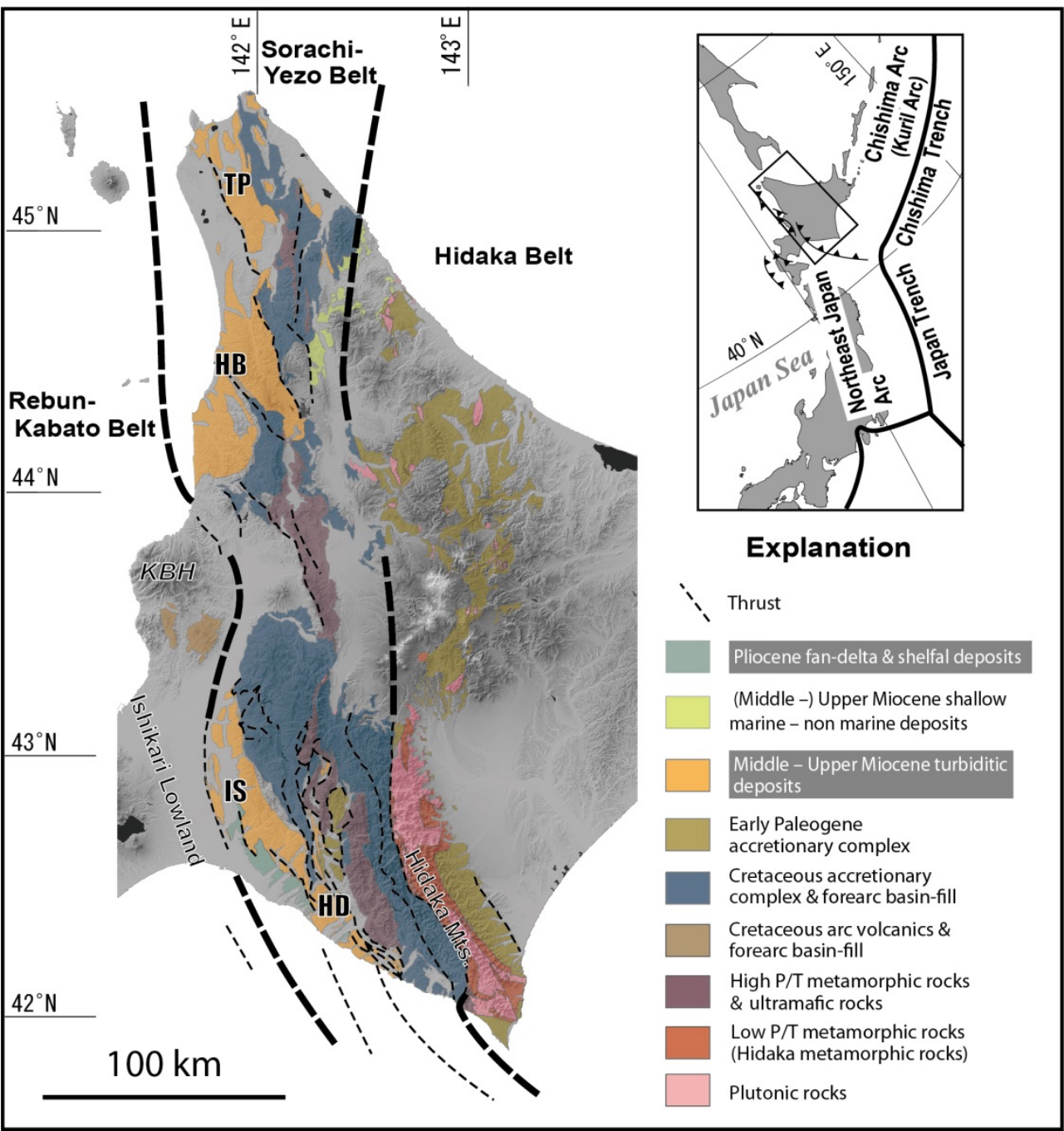

Figure 1. Simplified geologic map of central Hokkaido, northern island of Japan. The Miocene foreland basins were formed in the western zone of the Sorachi-Yezo Belt. The central part of the foreland basin area is constricted by the projection (Kabato basement high: KBH). Tenpoku Basin (TP), Haboro Basin (HB), Ishikari Basin (IS), and Hidaka Basin (HD) are major depressions separated by topographic highs (after [3]).

facies. These are settled in various areas from the outer to the inner foredeep settings. In this paper, the terms "outer", "axial" and "inner foredeep" follow the previous work [17, 18], (i.e., the outer foredeep is the most distal part of the foredeep above the foreland ramp; the axial foredeep is the central and deepest part of foredeep with relative flat basin floor; and the inner foredeep is the proximal part of foredeep along the thrust front characterized by steep slope 
and rough topography due to thrust propagation). The turbiditic deposits are covered with siliceous/diatomaceous and/or shelfal muddy deposits of the late Miocene to Pliocene ages (Figure 2).

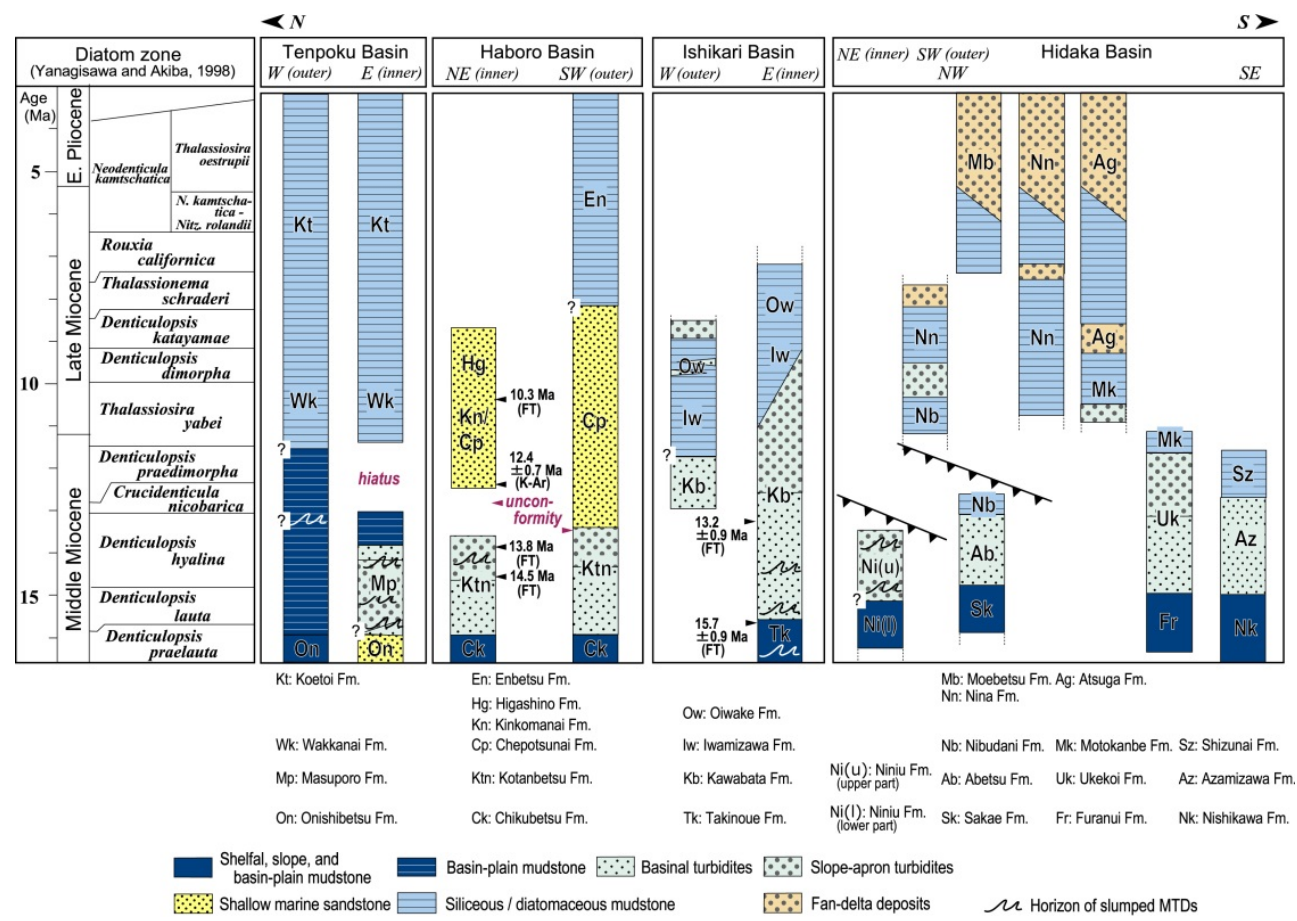

Figure 2. Stratigraphy of the middle Miocene to early Pliocene deposits in central Hokkaido. Depositional ages have been determined by diatom biostratigraphy and chronostratigraphic data. Diatom biostratigraphic zonation after [19]. Columns show the successions of inner (orogen-ward, proximal) and outer (foreland-ward, distal) areas of each depression.

\section{Basin geometry and stratigraphy}

\subsection{Tenpoku Basin}

The northernmost depression is $80 \mathrm{~km}$ wide and at least $60 \mathrm{~km}$ long (wider than other depressions later described, see Table 1), and is known as the Tenpoku Basin. The western half and the northern part of the basin extend to the Japan Sea (Figure 3). Because the fold-thrust propagation and resultant basin deformation is restrictive, a Middle to Late Miocene basin fill, 1000-2000 m thick, crops out only in the easternmost area. The Miocene axial foredeep is located around the present-day coastline along the Japan Sea, where, according to well data, the basin fill reaches its maximum thickness (ca. $4000 \mathrm{~m}$ ) [20]. 


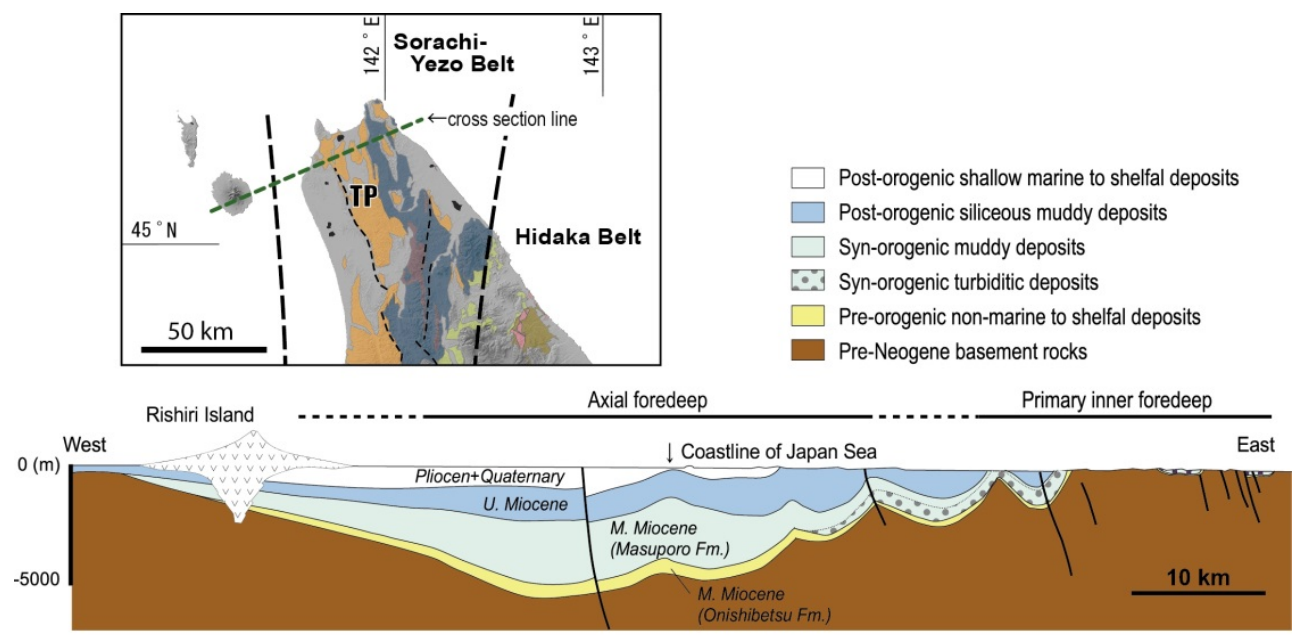

Figure 3. Cross section of the Tenpoku Basin (after [21]). Primary basin geometry is well preserved because of restricted later tectonic disturbances. See Figure 1 for legend in the index map.

In the easternmost outcrop, a middle Miocene turbiditic succession (the Masuporo Formation) is characterized by abundant mass-transport deposits (MTDs), such as slumped sand/mud interbeds and chaotic sand to gravel beds, bearing many intrabasinal blocks [20, 22-25] (Figure 4). It is noteworthy that the MTDs at the base of the Masuporo Formation rest directly on the shallow marine sandy deposits of the early Middle Miocene (the Onishibetsu Formation), which settled prior to the foreland basin subsidence. In the uppermost horizon of the turbiditic succession, mud-prone basinal turbidites and basin-plain mudstones are predominant, and the succession thus shows an overall fining-upward trend.

The basin fill fines also foreland-ward drastically, and the axial foredeep is filled mainly with basin-plain muddy deposits (2000-3000 m thick) [26]. As an exception, a $200 \mathrm{~m}$ thick slumped interval occurs in the upper part of this muddy succession [26]. This interval is characterized by muddy chaotic deposits containing granule-grade grains, although no detailed sedimentary features are described.

The entire part of the basin was covered by basin-plain muddy deposits in the late-Middle Miocene, after which siliceous/diatomaceous muddy deposits (>1000 m thick) were accumulated basin-wide during the late Miocene.

Although the sediment dispersal pattern in the Tenpoku Basin is not clearly understood, a clastic composition of basin fill, which is rich in granite and hornfels clasts, indicates a sediment supply from the Hidaka Belt in the east. 


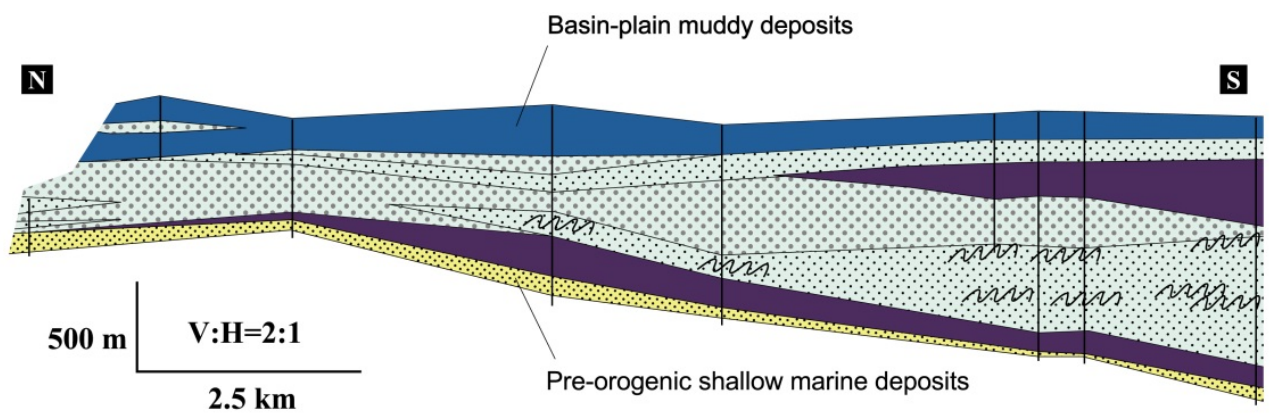

$\begin{array}{llll}\because \because \quad \begin{array}{l}\text { Thick-bedded conglomerates, sandstones } \\ \text { and sandstone/mudstone interbeds }\end{array} & \text { Sm Slumped sandstone/mudstone interbeds } \\ \because \quad & \text { Sandstone and mudstone interbeds } & \text { Measured section } \\ & \text { Slumped MTDs (debris flow deposits) }\end{array}$

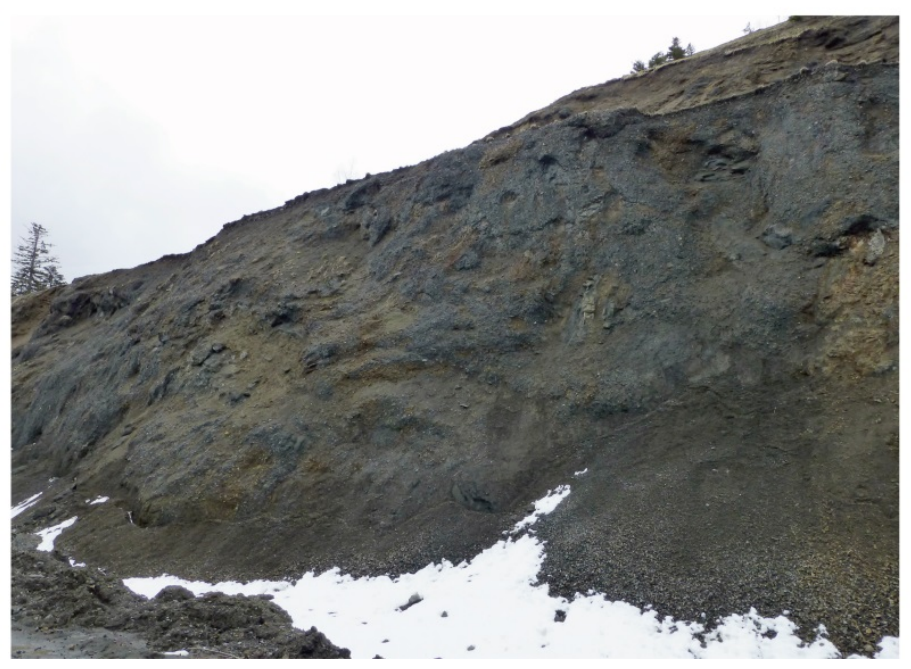

Figure 4. Basin-axial profiles of the middle Miocene turbidites at the eastern margin of the Tenpoku Basin (after [22]) (above), and representative photo of the slumped MTDs (below). The cliff is about $12 \mathrm{~m}$ high.

\subsection{Haboro Basin}

The stratigraphic and sedimentary architecture of the Haboro basin fill, (at least $50 \mathrm{~km}$ wide and $90 \mathrm{~km}$ long), has been well reconstructed by many studies (e.g. [2, 3, 14, 27]). A large part of the accommodation space is filled with 2000-3000 m thick middle Miocene turbidites (the Kotanbetsu Formation) composed of lower basinal turbidites and upper coarse-grained immature turbiditic deposits (slope-apron turbidites, to be discussed later) (Figure 5). The 
basinal turbidites are invariably underlain by relatively thin $(<100 \mathrm{~m})$ shelfal muddy deposits of the upper part of the Chikubetsu Formation. The blackish muddy deposits at the top of the Chikubetsu Formation indicate a condensed horizon formed during rapid basin subsidence [27]. At the southwestern margin of the basin, the turbiditic deposits show lateral onlap onto the early Miocene shallow-marine/non-marine deposits fringing the $\mathrm{KBH}$. On the other hand, the basin fill was exposed subaerially around $12 \mathrm{Ma}$ at the eastern margin of the basin.
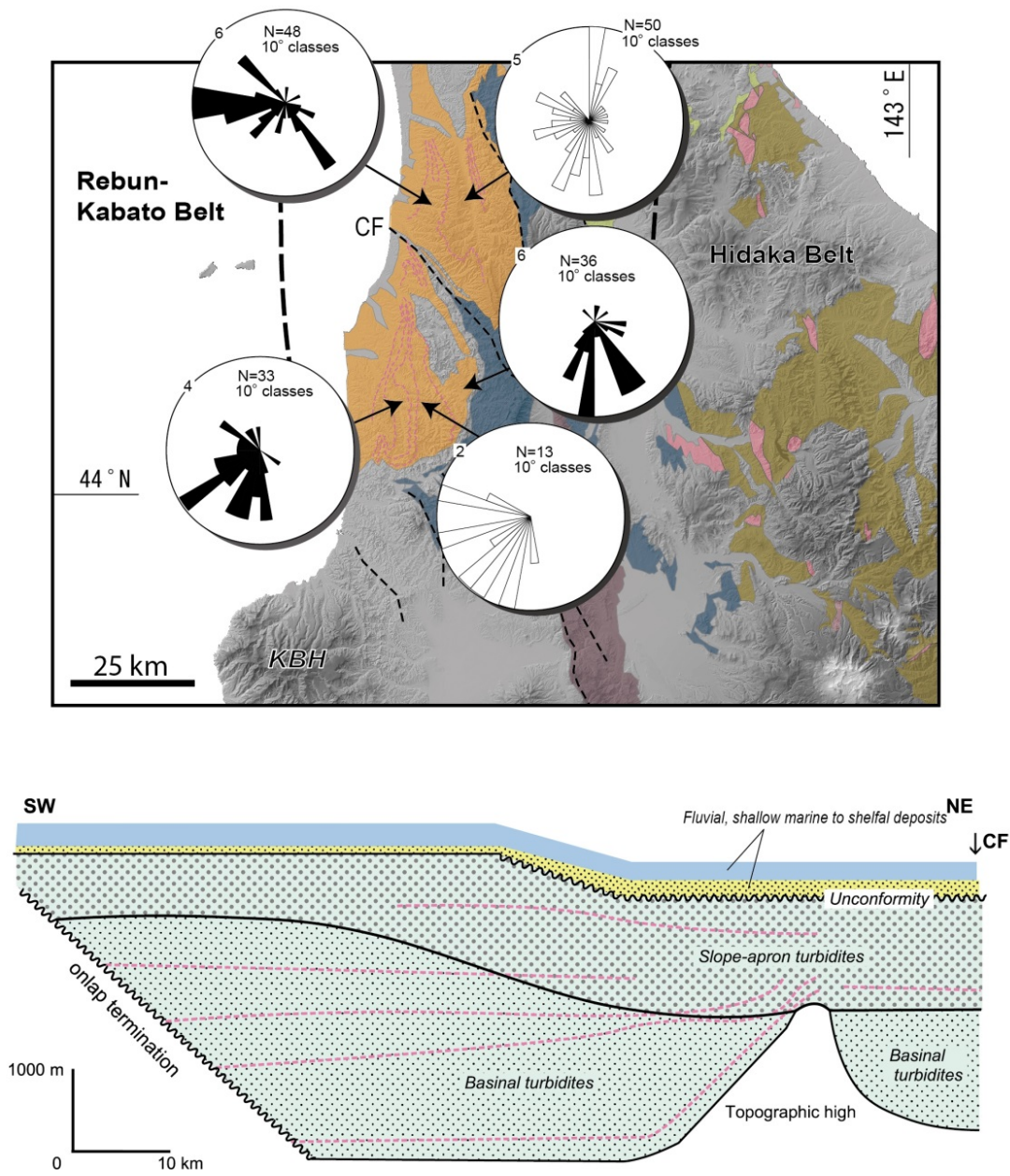

Figure 5. Rose diagrams showing paleocurrent directions of the middle Miocene turbidites in the Haboro Basin (above: compiled from [2, 14]), and transverse profile of the basin fill (below: modified from [2]). The solid and open petals of rose diagram mean the direction measured from sole-marks and clast fabric (solid) and cross lamination (open). Pink-colored dashed lines are stratigraphic markers (ash turbidite beds). CF: Chikubetsu Fault. See Figure 1 for legend of the index map. 
A north-south stretched topographic high lying parallel to the basin-axis separates an initial depression into two segments $[2,3,14,28]$. Basinal turbidites buried the segments progressively from the inner (eastern orogen-ward segment) to the outer (western foreland-ward segment), and flattened the irregular bottom of the basin (Figure 5). Slumped MTDs are developed, especially in the inner segment [27]. Subsequently deposited coarse-grained turbidites characterized by amalgamated and channelized sandy/gravelly beds are prograded on the basinal turbidites $[2,3]$. These turbiditc deposits contain abundant large granite clasts indicating a sediment supply from the Hidaka Belt in the east. Sole marks within the basinal turbidites in the central to southern outcrops reveal southwest-to-south directed flows. The coarse-grained turbidites found at the stratigraphically uppermost part of the northern outcrop reveal west-directed flow (Figure 5).

\subsection{Ishikari basin}

The Ishikari Basin is characterized by its very narrow basin geometry (Figure 6). At present, the Middle Miocene basin fill reveals a north-south stretched elongated distribution $(<15 \mathrm{~km}$ wide and $60 \mathrm{~km}$ long). Although the original dimension of the basin is uncertain because of the post-dated basin deformation, the strongly concentrated paleoflow data in the basin-axis direction indicates a confined basin floor (Figure 7). The primary western margin of the basin, where a thrust-front advanced during the Pliocene age [5], was bordered by horst structures formed from the basement rocks and the overlying Upper Oligocene to Lower Miocene strata.

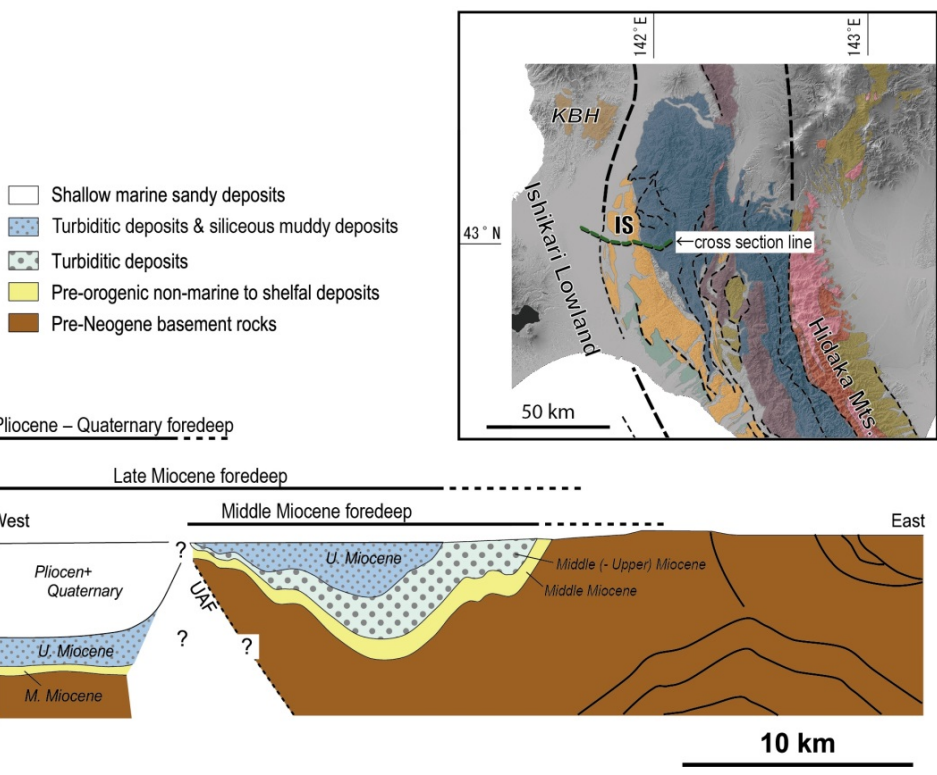

Figure 6. Cross section of the Ishikari Basin (after [6]) suggesting very narrow basin geometry concordant with strongly concentrated paleoflow data shown in Figure 7. UAF: Umaoi active fault. See Figure 1 for legend of the index map. 
The basin is filled mainly with lower basinal turbidites and upper coarse-grained slope-apron turbidites of the middle to late Miocene Kawabata Formation, 3500 m thick. The basinal turbidites buried the irregular basin floor and they onlap to the slope in the western and southern margins of the basin. The slope-apron turbidites are longitudinally prograded southward onto the basinal turbidites (Figure 8).
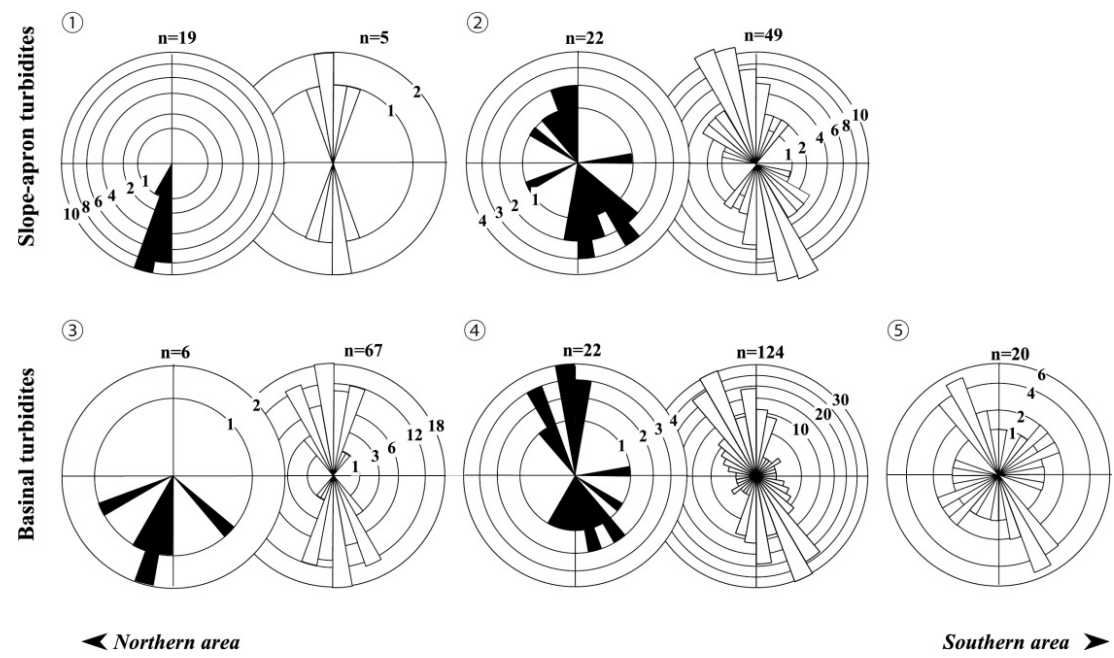

Figure 7. Rose diagrams showing paleocurrent directions of the middle to late Miocene tubidites in the Ishikari Basin. The solid and open petals of diagram mean the direction measured from flute marks and clast fabric (solid) and from groove marks and parting lineation (open). Note the diagrams are drawn with square root scaling. See Figure 8 for approximate localities of the measured data.

The basinal turbidites are underlain by shelfal, slope, and basin-plain muddy deposits (the early Middle Miocene Takinoue Formation). The muddy deposits are generally several hundreds of meters thick, but reach a thickness of $1000 \mathrm{~m}$ in local areas, where thick chaotic intervals (70-420 m thick), consisting of slump and debris flow deposits, occur [29]. The debris flow deposits notably contain abundant boulder-size serpentinite and sandstone blocks in addition to slate and chert cobbles.

Three chaotic intervals (slumped MTDs) are also encased within the basinal turbidites, and these consist of slump and debris flow deposits similar to the intervals in the Takinoue Formation. They lack serpentinite blocks, but contain granite cobbles-boulders, indicating a sediment supply from the Hidaka Belt [9]. Subsequently, clastic compositions changed synchronous with the change in sedimentary style from basinal turbidites to coarse-grained slope-apron turbidites. Abundant granite and hornfels grains in the basinal turbidites decrease upward. This is counterbalanced by an increase of green rocks, chert, and coeval andesiticrhyolitic volcanic grains in the slope-apron turbidites (Figure 9). Such change in clastic composition indicates that a sediment provenance advanced from the Hidaka Belt to the Sorachi-Yezo Belt. 


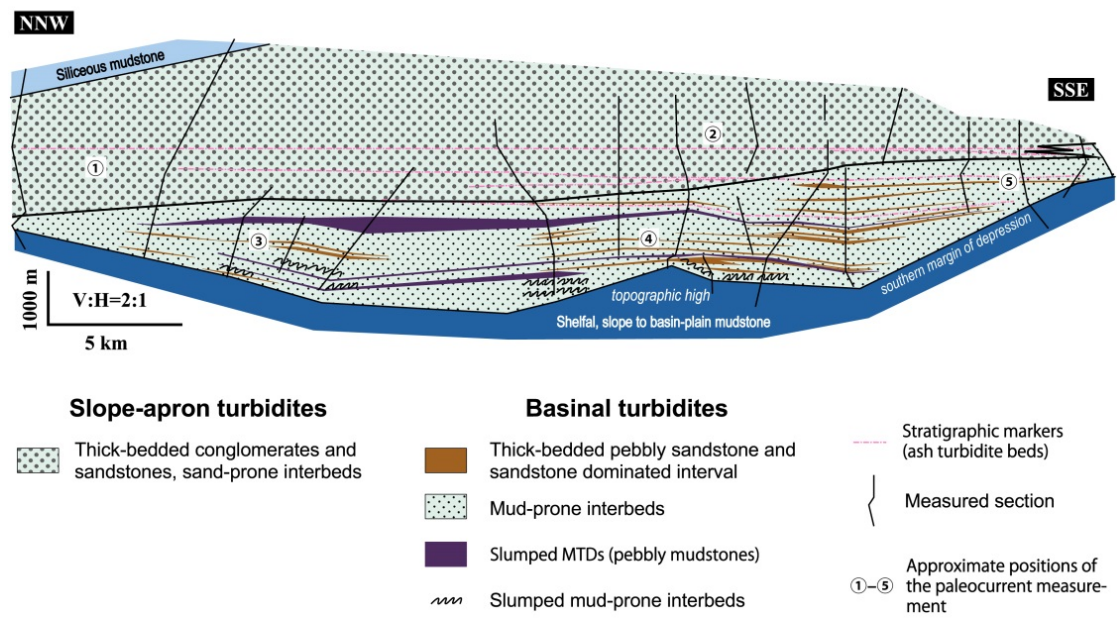

Figure 8. Basin-axial sedimentary profile of the Ishikari basin fill.

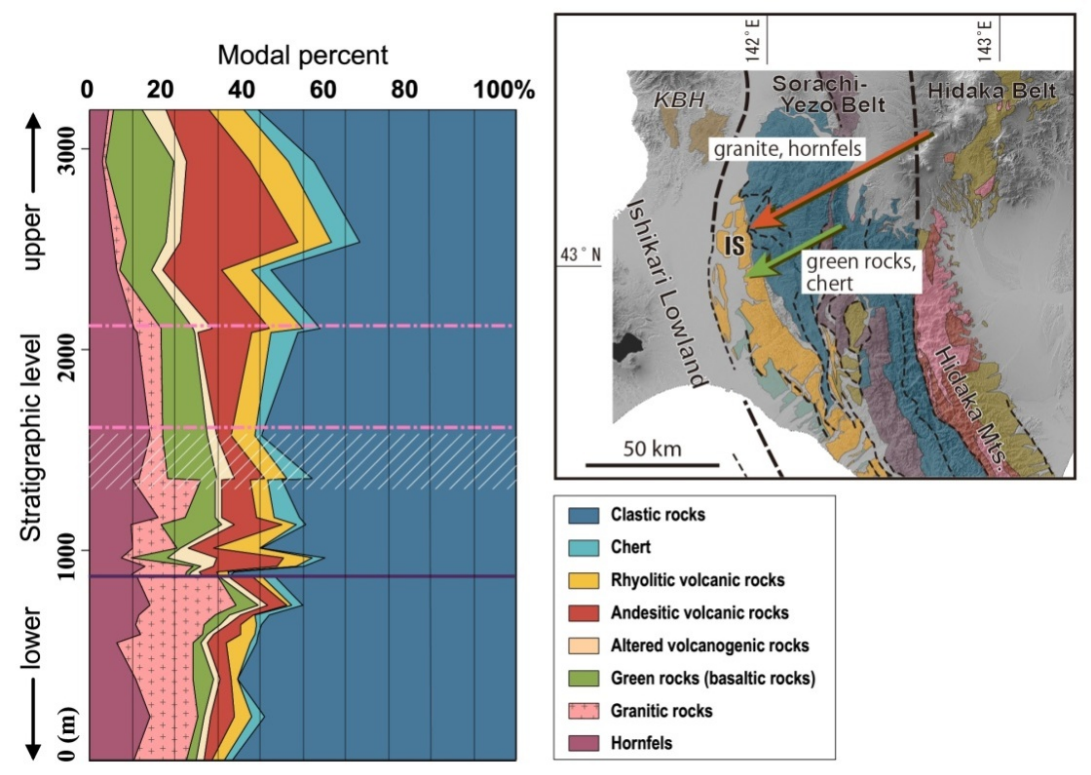

Figure 9. Modal evolutions of the lithic fragments in the coarse-grained sand to granule-grade turbiditic beds filling the Ishikari Basin, measured by point-counting method for thin section. White diagonal hatch indicates the horizon of the change in sedimentary style from basinal to slope-apron turbidite system. Stratigraphic level is based on the thickness. 


\subsection{Hidaka Basin}

The Hidaka Basin, (>30 km wide and $70 \mathrm{~km}$ long), is fragmented by thrust propagation. The deformation is especially intensive in the eastern area. Depositional ages of the basin fill are progressively younger to the west (Figure 10).
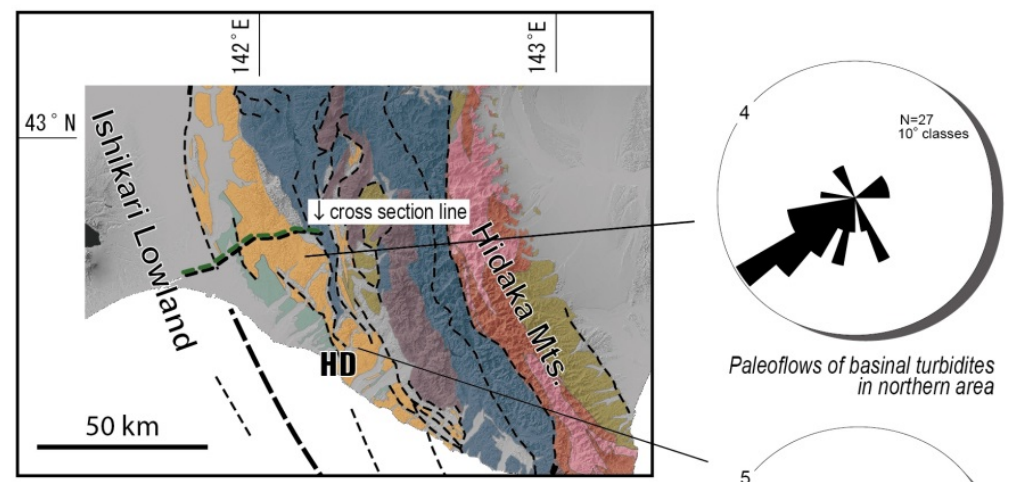

Paleoflows of basinal turbidites in northern area

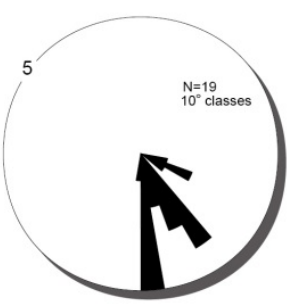

Paleoflows of slope-fan deposits

Fan-delta deposits interfingered with shelfal muddy deposits

Turbiditic deposits and siliceous muddy deposits

Turbiditic deposits

Pre-orogenic non-marine to shelfal deposits and volcaniclastics.

Pre-Neogene basement rocks

Pliocene - Quaternary foredeep

Late Miocene foredeep

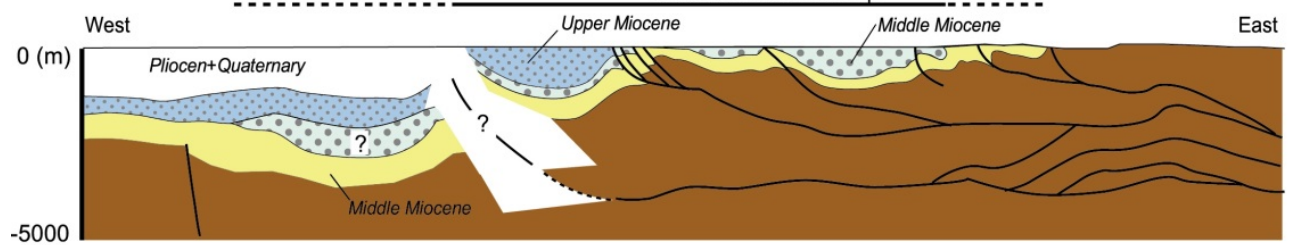

$10 \mathrm{~km}$

Figure 10. Cross section of the Hidaka Basin (after [6]). Paleoflow data are measured from flute marks and AMS (anisotropy of magnetic susceptibility) fabrics of the Middle Miocene turbidites (compiled after [30, 31, 33]). See Figure 1 for legend of the index map.

In the eastern margin of the basin, pre-orogenic shallow marine to shelfal muddy deposits of the early-Middle Miocene age are widely distributed (the lower part of the Niniu Formation and its correlatives, several hundred meters thick). These muddy deposits are locally overlain by turbiditic deposits accompanied with slumped MTDs (the upper part of the Niniu Formation, $>500 \mathrm{~m}$ thick). A lenticular gravelly body (slope-fan deposits, which are discussed later), 
$1000 \mathrm{~m}$ thick and $10 \mathrm{~km}$ width, is locally developed (the eastern part of the Abetsu and the Ukekoi Formations). The gravelly deposits pass rapidly down-dip to the south into the basinal turbidites [30].

\begin{tabular}{|c|c|c|c|c|c|c|}
\hline \multirow[b]{2}{*}{ Locality } & \multirow{2}{*}{\begin{tabular}{c|} 
Dimension \\
Width and length at \\
middle Miocene age
\end{tabular}} & \multicolumn{3}{|c|}{ Stratigraphy and sedimentary features } & \multirow[b]{2}{*}{$\begin{array}{c}\text { Tectonic } \\
\text { deformation }\end{array}$} & \multirow[b]{2}{*}{ Remarks } \\
\hline & & $\begin{array}{c}\text { Pre-orogenic } \\
\text { (underlying deposits) }\end{array}$ & $\begin{array}{l}\text { a: primary inner foredeep, b: axial } \\
\text { foredeep, c: transition from axial to } \\
\text { inner foredeep }\end{array}$ & $\begin{array}{l}\text { Post-orogenic } \\
\text { (overlying deposits) }\end{array}$ & & \\
\hline Tenpoku & $80 \mathrm{~km},>60 \mathrm{~km}$ & $\begin{array}{l}\text { Shallow marine sand- } \\
\text { stone }\end{array}$ & $\begin{array}{l}\text { a: MTD dominant, coarse-grained } \\
\text { turbiditic deposits (1000-2000 m thick) } \\
\text { b: Muddy turbidites and basin-plain } \\
\text { muddy de-posits (2000-3000 m thick) }\end{array}$ & $\begin{array}{l}\text { Siliceous / diatoma- } \\
\text { ceous mudstone } \\
\text { (1000-2000 m thick) }\end{array}$ & $\begin{array}{l}\text { Restrictive } \\
\text { Declining thrust } \\
\text { activity in early Late } \\
\text { Miocene }\end{array}$ & $\begin{array}{l}\text { Slumped interval } \\
\text { (200 m thick) in the } \\
\text { basin-plain muddy } \\
\text { deposits of axial } \\
\text { foredeep }\end{array}$ \\
\hline Haboro & $>50 \mathrm{~km}, 90 \mathrm{~km}$ & Shelfal mudstone & $\begin{array}{l}\text { a: MTD dominant, coarse-grained } \\
\text { turbiditic deposits, details unknown } \\
\text { b: Basinal turbidites (1500-3000 m } \\
\text { thick) } \\
\text { c: Slope-apron turbidites (1000-1500 } \\
\text { m thick) }\end{array}$ & $\begin{array}{l}\text { Shallow marine sand- } \\
\text { stone (<500 } \mathrm{m} \text { thick) } \\
\text { and subsequently } \\
\text { aggraded diatoma- } \\
\text { ceous mudstone } \\
\text { (500-1000 } \mathrm{m} \text { thick) }\end{array}$ & $\begin{array}{l}\text { Moderate } \\
\text { The western margin } \\
\text { of the basin is } \\
\text { bordered by KBH } \\
\text { Declining thrust } \\
\text { activity during late } \\
\text { Miocene? }\end{array}$ & $\begin{array}{l}\text { Initially segmented } \\
\text { axial foredeep }\end{array}$ \\
\hline Ishikari & >>15 km, $60 \mathrm{~km}$ & Shelfal mudstone & $\begin{array}{l}\text { a: Not preserved } \\
\text { b: Slope to basin-plain mudstones } \\
\text { ( }<500 \mathrm{~m} \text { ) and overlying basinal } \\
\text { turbidites (300-2400 m thick) } \\
\text { c: Slope-apron turbidites (2000-2800 } \\
\text { m thick) locally accompanied with } \\
\text { siliceous / diatomaceous mudstones }\end{array}$ & - & $\begin{array}{l}\text { Moderate-high } \\
\text { The western margin } \\
\text { of the basin is } \\
\text { bordered by KBH } \\
\text { Continuing thrust } \\
\text { activity to the } \\
\text { present? }\end{array}$ & $\begin{array}{l}\text { Very narrow } \\
\text { geometry } \\
\text { Longitudinal } \\
\text { sediment transport } \\
\text { Pebbly mudstones in } \\
\text { the basinal turbidite } \\
\text { succession }\end{array}$ \\
\hline Hidaka & $>30 \mathrm{~km},>70 \mathrm{~km}$ & Shelfal mudstone & $\begin{array}{l}\text { a: MTD dominant, coarse-grained } \\
\text { turbiditic deposits ( }>500 \mathrm{~m} \text { thick), } \\
\text { locally developed slope-fan deposits } \\
\text { (1400 m thick) } \\
\text { b: Basinal turbidites (middle Miocene, } \\
1500 \mathrm{~m} \text { thick), shelf-type fan-delta } \\
\text { (Pliocene, 1000-1800 m thick) } \\
\text { c: Slope-apron turbidites (1100-2600 } \\
\text { m thick) }\end{array}$ & - & \begin{tabular}{|l|} 
\\
High \\
Continuing thrust \\
activity to the present
\end{tabular} & $\begin{array}{l}\text { Depocenter } \\
\text { migration }\end{array}$ \\
\hline
\end{tabular}

Table 1. Summary of the features of the depressions formed in the Miocene foreland basin area, Hokkaido, northern Japan. 
In the central zone of the outcrops, middle to late Miocene turbiditic deposits (3000 m thick) are distributed (the western part of the Abetsu and the Ukekoi Formations, and the Azamizawa Formation). Basinal turbidites developed in the middle Miocene age show a slightly southward-fining megatrend. Paleocurrent directions show dominant southwestward flows in the northern area (Figure 10), although the basin-wide tendency is undefined. The basinal turbidites are overlain by late Miocene siliceous sandy mudstones and coarse-grained slopeapron turbidites [30,31], but the detailed sedimentary style of the late Miocene deposits remains unknown. The sandy mudstones yield fossils of shallow marine shells [30].

In the westernmost zone of the outcrops, Pliocene sandy to gravelly deposits interfinger with and/or are prograded onto shelfal sandy mudstones [32]. The sand and gravelly beds often show large-scale cross bedding. The distribution area of the Pliocene deposits is roughly separated from the Miocene turbidites by a thrust fault parallel to the basin axis. The total thickness of the Pliocene deposits reaches 1500-2000 m.

The detrital composition of the Middle Miocene to Pliocene succession in the Hidaka Basin records an exhumation history of deep-seated lower crustal rocks of the Chishima Arc (the Hidaka metamorphic rocks) $[9,15,30]$.

\section{Sedimentary processes}

\subsection{Primary wedge-top to inner foredeep}

A sedimentary succession within the primary inner foredeep can be observed in the eastern Tenpoku Basin (Figure 4). The sedimentary fill typically includes syn-orogenic packages of chaotic MTDs. The MTDs rest directly on the pre-orogenic shallow marine sandstones and often bear abundant intrabasinal blocks. Thus, the primary inner foredeep setting was quite unstable because of rapid syn-depositional subsidence and thrusting. The laterally discontinuous distribution of MTDs and sandy/gravelly turbiditic deposits with locally presented sand/ mud interbeds suggests the ponding of frequently generated dense flows in small accommodation spaces of the irregular basin floor. As discussed in the next subsection, a large collapse event also resulted in a thick accumulation of cohesive debris flow deposits in the axial foredeep setting.

In the Hidaka Basin, a thick gravelly body is locally present in the boundary zone between the inner and the axial foredeep. Its basin-axial paleoflow direction suggests the development of a sediment conduit controlled by the thrust fault itself (cf. [34]). The gravelly body rapidly passes down-dip into the basinal turbidites of the axial foredeep and is interpreted as slopefan deposits fed by a northern point source [30].

The sedimentary features of primary wedge-top basin (i.e., basins on thrust sheets and located at proximal side of inner foredeep) during the early syn-orogenic phase of foreland basin evolution are not evident. Non-marine to shallow marine deposits of middle to late Miocene age occur adjacent to the Tenpoku and Haboro Basins, but most of the deposits were formed during the post-orogenic phase in the northern collision zone. 


\subsection{Axial foredeep}

In the Tenpoku Basin, much of the sandy to gravelly deposits were trapped in the accommodation space at the inner foredeep. As a result, the axial foredeep was filled mainly by basinplain muddy deposits more than 2000 m thick. A 200-m-thick chaotic interval, containing exceptionally of sandy to granular grains in muddy matrices, occurs in the basin-plain muddy succession, suggesting large mass failure events in the proximal setting (i.e., the inner foredeep).

Except for the Tenpoku Basin, the axial foredeep is filled with a 1000-3000 m thick turbiditic succession mainly consisting of basinal turbidites (Figure 11a). The basinal turbidites are underlain by shelfal, slope, and/or basin-plain, muddy sediments with a condensed interval of blackish mud at their top, showing gradual but larger amount subsidence compared to the primary inner foredeep setting.

The basinal turbidites consists of monotonous interbeds of parallel-sided sand/mud beds. Spatiotemporally, they show no apparent coarsening or fining facies trends, other than a sandier upward trend in their basal section. The monotonous interbeds incorporate with isolated beds and packages of thick-bedded pebbly sandstone several tens of meters thick. These package-forming beds are more or less graded and unchannellized, and rarely show bed amalgamation. The concentration of paleoflows along the basin axis suggests that flows entering from lateral entry point(s) were deflected and transformed to basin-axial flows, which may explain the lack of an ordered facies trend. The basinal turbidites are transported by efficient turbidity currents in the confined basin plain (sense [35]).

Slumped MTDs intervene in the basinal turbidites of the axial foredeep and are particularly well developed in the Ishikari Basin. The MTDs mainly consist of debris flow deposits (pebbly mudstone) that contain many intrabasinal blocks and extrabasinal cobbles-boulders outsized for the succession (Figure 11b). These debris flow deposits are traceable basin-wide, suggesting large collapse events at the basin margin settings (i.e., the inner foredeep and wedge-top). MTDs of a similar scale do not exist in the slope-apron turbidites of the upper stratigraphic level.

\subsection{Transition from axial to inner foredeep}

Temporally, an axial foredeep setting evolves into an inner foredeep setting owing to thrust propagation. Other than in the Tenpoku Basin, the basinal turbidites of the axial foredeep are overlain by a turbiditic succession consisting of poorly sorted and coarser-grained sand to gravel beds interfingered with monotonously interbedded sandstone and sandy mudstone. As a whole, these coarse-grained deposits form a gravelly wedge prograded on the basin floor of the inner to the axial foredeep settings. In the Haboro Basin, the gravelly wedge prograded foreland-ward, while the wedge in the narrow Ishikari Basin shows axial progradation southward.

The thickly bedded sandstones and disorganized cobble to boulder conglomerates show an erosive base and frequent bed amalgamation (Figure 11c, 11d). These coarser-grained beds 

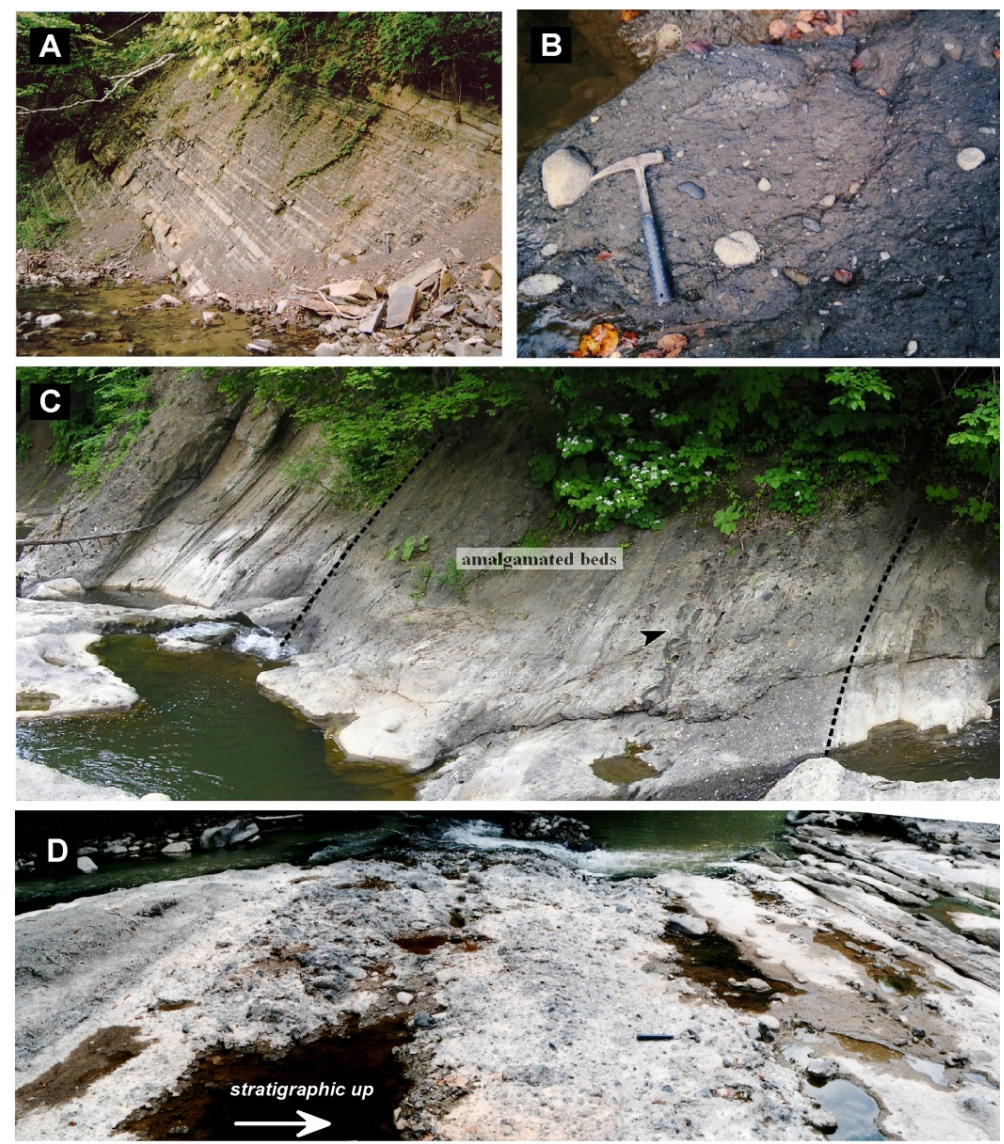

Figure 11. Field occurrence of the Miocene turbidites in the Ishikari Basin. (A) Monotonous, mud-prone interbeds of basinal turbidites, (B) extrabasinal-cobble bearing pebbly mudstone in the basinal turbidite succession, (C) sand-prone interbeds and an amalgamated sand bed more than $5 \mathrm{~m}$ thick in the slope-apron turbidites, arrow: interval of aligned mudclasts (D) amalgamated stack of disorganized conglomerates and coarse-grained sandstones interpreted as fills of multiple chutes.

show variable facies such as disorganized, massive, cross-stratified, crudely laminated to well laminated, or crudely graded to graded bedding. Some beds consist of gravel, sand, and minor thin mud layers partitioned by surfaces with abrupt grain-size reduction (tripartite beds). The sand beds frequently contain plant debris and the associated mudstones are sandy and bioturbated. Thus, these deposits were transported by poorly-efficient dense flows, and filled multiple chutes developed at relatively proximal and shallower settings than the former basinplain setting (e.g., the slope-apron setting: [36]). The paucity of muddy deposits can probably be attributed to the finer-grained dilute portions of the flows being stripped off and bypassing the area because of consistent infilling of the confined basin (e.g., [37]). In addition, as discussed 
in the Chapter 5, changes in proximity of sediment source and/or in lithologic compositions in the orogen also caused a decrease in the fine-grained fraction.

\subsection{Basin migration and Pliocene foredeep}

Pliocene gravelly deposits crop out on the northwestern side of the Hidaka Basin and interfinger with shallow marine to shelfal deposits. Their distribution, distinct from that of the Miocene basin fill, suggests a major foreland-ward shift of the depocenter. Although the sedimentary processes of the Pliocene deposits are poorly known, the spatiotemporal distribution of the gravelly body suggests cyclic progradation of shelf-type fan-delta systems toward the west [32] or south to southwest (Takano, personal communication).

\subsection{Post-orogenic sedimentation}

In the Tenpoku Basin, the MTD dominated coarse clastic wedge is overlain by mud-prone interbeds and subsequently developed basin-plain muddy deposits, suggesting rapidly declining tectonic activity in the northern area of the collision zone by the early Late Miocene. Subsequently accumulated siliceous/diatomaceous muddy deposits buried the "abandoned foredeep." A recent study suggested that the accommodation space of the late Miocene age was maintained as a pull-apart depression along a right-stepping dextral fault system transformed from the former transpressional thrust system [38]. The siliceous/diatomaceous deposits are interpreted as siliceous muddy turbidites [39]. The declining thrust activity resulted in starvation of terrigenous sediment input to the Tenpoku Basin. Siliceous tests, originating from siliceous phytoplankton blooms in the photic zone, were alternately transported by laterally induced muddy turbidity currents [38, 39].

Notably, diatom productivity dramatically increased in the North Pacific and paleo-Japan Sea during the late Miocene [40]. As a result, syn-orogenic turbiditic deposits in the Ishikari and Hidaka Basins are also accompanied by similar muddy deposits during the late Miocene to Pliocene ages.

\section{Tectonically controlled basin geometry and stratigraphic architecture}

It is supposed that along the collision zone in central Hokkaido, the spatial variation in geodynamic properties of the foreland lithosphere is small, because of the assumption of a uniform geological composition, geotectonic history, and geothermal structure throughout the region. Thus, the variations in basin geometry and stratigraphic/sedimentary architecture for each depression are attributed to the regional difference in the degree of horizontal compression and resultant basin deformation.

The wider geometry of the Tenpoku Basin is the result of restrictive basin deformation. Many of the turbiditic deposits are confined to the inner foredeep and the axial foredeep is filled with muddy deposits. This condition is common to other depressions at the initial 
stage of basin evolution. Conversely, the thick accumulation of turbiditic deposits in the axial foredeep requires persistently high-relief basin physiography from the hinterland to the basin plain and high-volume sediment input.

Consistent basin infilling and/or thrust propagation results in shallowing of the foredeep and a transition in sedimentary style [37]. In addition, synchronous changes in the detrital composition in the Ishikari and Hidaka Basins suggest a close relationship between the sedimentary style in the foredeep and structural deformation in the hinterland (see discussion of [41]). In the Ishikari Basin, the compositional change in the detritus suggests lateral growth of the orogen (extension from the Hidaka Belt to the Sorachi-Yezo Belt). The proximity between the depocenter and the newly emergent source area resulted in an increase in the coarser-grained fractions and generation of relatively poorly-efficient flows. In contrast, the evolution of the detritus composition in the Hidaka Basin implies exhumation of deep-seated crustal rocks. Thus, the increase in coarse-grained deposits through poorly-efficient dense flows is attributed to an increase in the distributional area of crystalline rocks in the Hidaka Belt (Hidaka metamorphic rocks). Although the detrital compositional signal is unclear in the Haboro Basin, subaerial erosion of the basin fills in the eastern area suggests syn-depositional thrusting near the basin margin.

A similar succession, consisting of lower basinal turbidites and upper coarser-grained turbiditic deposits, is well documented from the Miocene foredeep turbidites in the Northern Apennines [e.g., 42]. In that area, the change in sedimentary style was controlled by the narrowing and closure (shallowing) of the foredeep due to thrust propagation [42]. In Hokkaido, in contrast, the stratigraphic architecture does not show obvious narrowing of the foredeep depressions. The coarse-grained slope-apron turbidites occur basin-wide and their thickness is approximately the same as that of the basinal turbidites. In addition, they are covered with relatively thick siliceous/diatomaceous muddy deposits. Nevertheless, the depressions appear to shallow gradually upward, as indicated by the dominance of bioturbation, plant debris, and shell fossils in the Late Miocene basin fills. Despite the migration of the depocenter in the Hidaka Basin, the depth of the depocenter gradually decreases foreland-ward until the Pliocene. Initial regional shallowing occurred around 13-14 Ma, beginning in the northern foreland area. An eustatic sea-level fall [43] is not sufficient to explain such a long-term gradual shallowing of the basin; however, a flexural rebound of underlying lithosphere [44] can explain such shallowing. The rebound was probably caused by isostatic readjustment for a thinning orogen or decreased horizontal compressional stress corresponding to a gradual or stepwise decline of thrust activities in central Hokkaido [45, 46].

\section{Conclusions}

This paper provides an introduction to a tectonically controlled foreland basin stratigraphy at the arc-arc collision zone of Miocene age in Hokkaido, northern Japan. Spatial 
differences in the degree of tectonic disturbance caused variations in stratigraphic/sedimentary architecture between the separately developed depressions in the foreland basin area. Limited tectonic activity resulted in trapping of coarse-grained deposits in the inner foredeep setting. Thick muddy deposits filled the sediment-starved and abandoned axial foredeep. Moderate to high thrust activity formed turbiditic successions several thousand meters thick in the axial foredeep. Progressed thrusting caused an increase in coarsergrained sediment-input to the foredeep and the sedimentary style changed from the basinal turbidites by efficient-flows to the slope-apron turbidites by poorly-efficient flows. The longterm shallowing of the foreland basin area can be explained by lithospheric flexural rebound caused by the isostatic readjustment for a thinning orogen and/or decreased horizontal compressional stress due to a gradual or stepwise decline of thrust activities in central Hokkaido.

\section{Acknowledgements}

The invitation of the editor, Dr. Y. Itoh, to submit this manuscript is highly appreciated. The early version of the manuscript is greatly improved by constructive comments by reviewers (Y. Itoh and O. Takano). The following people are thanked for discussion and helpful suggestion: K. Arita, K. Sawada, S. Furota, T. Nakajima, T. Watanabe, S. Ohtsu, and M. Kawamura.

\section{Author details}

Gentaro Kawakami*

Address all correspondence to: kawakami-gentaro@hro.or.jp

Geological Survey of Hokkaido, Hokkaido Research Organization, Japan

\section{References}

[1] Allen PA., Homewood PN. Foreland Basins. IAS Special Publication 8. Oxford: Blackwell Science; 1986.

[2] Hoyanagi K. Progradational lithofacies change of turbidite sequence, Middle Miocene Kotambetsu Formation, central Hokkaido, Japan. Journal of the Geological Society of Japan 1989; 95: 509-525.

[3] Hoyanagi K. Coarse-grained Turbidite Sedimentation resulting from the Miocene Collision Event in Central Hokkaido, Japan. In: Taira A., Masuda F. (eds) Sedimenta- 
ry Facies in the Active Plate Margin. Tokyo: Terra Scientific Publishing Company (TERRAPUB); 1989. P689-709.

[4] Kimura G. Collision orogeny at arc-arc junctions in the Japanese Islands. The Island Arc 1996; 5: 262-275.

[5] Kato N., Sato H. Active tectonics in the axial zone of Hokkaido -an example from the Umaoi Hills area-. Chikyu Monthly 2002; 24: 481-484.

[6] Kazuka T., Kikuchi S., Ito T. Structure of the foreland fold-and-thrust belt, Hidaka Collision Zone, Hokkaido, Japan: re-processing and re-interpretation of the JNOC seismic reflection profiles 'Hidaka' (H91-2 and H91-3). Bulletin of the Earthquake Research Institute, University of Tokyo 2002; 77: 97-109.

[7] Ueda H., Kawamura M., Niida K. Accretion and tectonic erosion processes revealed by the mode of occurrence and geochemistry of greenstones in the Cretaceous accretionary complexes of the Idonnappu Zone, southern central Hokkaido, Japan. The Island Arc 2000; 9: 237-257.

[8] Osanai Y., Komatsu M., Owada M. Metamorphism and granite genesis in the Hidaka Metamorphic Belt, Hokkaido, Japan. Journal of Metamorphic Geology 1991; 9: 111-124.

[9] Kawakami G., Ohira H., Arita K., Itaya T., Kawamura M. Uplift history of the Hidaka Mountains, Hokkaido, Japan: a thermochronologic view. Journal of the Geological Society of Japan 2006; 112: 684-698.

[10] Tsuchi R. Neogene events in Japan and the Pacific. Palaeogeography, Palaeoclimatology, Palaeoecology 1990; 77: 355-365.

[11] Nagata M., Kito N., Niida K. The Kumaneshiri Group in the Kabato Mountains: the age and nature as an Early Cretaceous volcanic arc: Monograph of the Association for the Geological Collaboration in Japan 1986; 31: 63-79.

[12] Hoyanagi K., Miyasaka S., Watanabe Y., Kimura G., Matsui M. Depositions of turbidites in the Miocene collision zone, central Hokkaido. Monograph of the Association for the Geological Collaboration in Japan 1986; 31: 265-284.

[13] Takahashi K. Sedimentological analysis on pebbles from Tertiary conglomerates in north Hokkaido, Japan. Report of the Geological Survey of Hokkaido 1974; 46: 17-43.

[14] Okada H., Tandon SK. Resedimented Conglomerates in a Miocene Collision Suture, Hokkaido, Japan. In: Koster EH., Steel RJ. (eds) Sedimentology of Gravels and Conglomerates. Memoir of Canadian Society of Petroleum Geologists 10. Calgary: Canadian Society of Petroleum Geologists; 1984. P 413-427.

[15] Miyasaka S., Hoyanagi K., Watanabe Y., Matsui M. Late Cenozoic mountain-building history in central Hokkaido deduced from the composition of conglomerate. Monograph of the Association for the Geological Collaboration in Japan 1986; 31: 285-294. 
[16] Kawakami G., Arita K., Okada T., Itaya T. Early exhumation of the collisional orogen and concurrent infill of foredeep basins in the Miocene Eurasian - Okhotsk Plate boundary, central Hokkaido, Japan: inferences from K-Ar dating of granitoid clasts. The Island Arc 2004; 13: 359-369.

[17] Mutti E., Tinterri R., Benevelli G., di Biase D., Cavanna G. Deltaic, mixed and turbidite sedimentation of ancient foreland basins. Marine and Petroleum Geology 2003; 20: 733-755.

[18] Roveri M., Ricci Lucchi F., Lucente CC., Manzi V., Mutti E. Part III Stratigraphy, facies and basin fill history of the Marnoso-Arenacea Formation. In: Mutti E., Ricci Lucchi F., Roveri, M. (eds) Revisiting turbidites of the Marnoso-arenacea Formation and their basin-margin equivalents: problems with classic models. Excursion guidebook of the workshop organized by Dipartimento di Scienze della Terra, (Università di Parma) and Eni-Division Agip for the 64th EAGE Conference and Exhibition, Florence (Italy), May 27-30; 2002. III1-26.

[19] Yanagisawa Y., Akiba F. Refined Neogene diatom biostratigraphy for the northwest Pacific around Japan, with an introduction of code numbers for selected diatom biohorizons. Journal of the Geological Society of Japan 1998; 104: 395-414.

[20] Takahashi K., Fukusawa H., Wada N., Hoyanagi K., Oka T. Neogene stratigraphy and Paleogeography in the Area along the Sea of Japan of northern Hokkaido. Earth Science (Chilyu Kagaku) 1984; 38: 299-312.

[21] Hokkaido Mining Industry Promotion Committee. Petroleum and Natural Gas Resources in Hokkaido: Exploration and Development in 1977-1988. Sapporo: Hokkaido Mining Industry Promotion Committee; 1990.

[22] Mitani K., Saito N., Osanai H. Oil and natural gas: from the Masuporo anticline to northern Tenpoku oil field area. Report of the geological resources in Hokkaido 1962; 79: $1-16$.

[23] Mitani K., Saito N., Matsushita K., Osanai H. Oil and natural gas: from the headwaters of the Masuporo River and its southern side area to northern Tenpoku oil field area. Report of the geological resources in Hokkaido 1963; 88: 1-16.

[24] Hirooka E. Petroleum geological study on Tenpoku district in Hokkaido, Japan. Journal of the Japanese Association for Petroleum Technology 1962; 27: 113-134.

[25] Motoyama I., Nakamura S. Radiolarian biostratigraphy of the Miocene Masuporo and Wakkanai formations of the Uruyagawa section, Wakkanai, Hokkaido, Japan, with special reference to unconformity. Journal of the Geological Society of Japan 2002; 108: 219-234.

[26] Hokkaido Mining Industry Promotion Committee. Petroleum and Natural Gas Resources in Hokkaido: Exploration and Development in 1968-1976. Sapporo: Hokkaido Mining Industry Promotion Committee; 1979. 
[27] Takahashi K., Kiminami K. Sedimentation of the Miocene Kotanbetsu Formation around the Haboro dome. Earth Science (Chilyu Kagaku) 1983; 37: 250-261.

[28] Matsuno K. The deposition of the sedimentary basin of the Kotambetsu Formation. Journal of the Japanese Association for Petroleum Technology 1958; 23: 19-21.

[29] Kanno S., Ogawa H. Geology of the Tertiary System in the Momijiyama-Takinoue district, Yubari City, Japan. Journal of the Geological Society of Japan 1963; 69: 262-278.

[30] Hoyanagi K., Mito N., Yoshioka M., Miyasaka M., Watanabe Y., Matsui M. Stratigraphy and sedimentology of the Miocene sediments in the southern part of the Ishikari-Teshio Belt, Hokkaido, Japan. Earth Science (Chilyu Kagaku) 1985; 39: 393-405.

[31] Kawakami G., Shiono M., Kawamura M., Urabe A. Koizumi I. Stratigraphy and depositional age of the Miocene Kawabata Formation, Yubari Mountains, central Hokkaido, Japan. Journal of the Geological Society of Japan 2002; 108: 186-200.

[32] Sagayama T., Hoyanagi K., Miyasaka S. Diatom biostratigraphy and the stage of Neogene coarse-grained deposits in the Hidaka coastal land, central Hokkaido, Japan. Journal of the Geological Society of Japan 1992; 98: 309-321.

[33] Itoh Y., Tamaki M., Takano O. Rock Magnetic Properties of Sedimentary Rocks in Central Hokkaido: Insights into Sedimentary and Tectonic Processes on an Active Margin. In Itoh, Y., ed., Mechanism of Sedimentary Basin Formation - Multidisciplinary Approach on Active Plate Margins (this volume).

[34] Covault JA., Graham SA. Turbidite architecture in proximal foreland basin-system deep-water depocenters: insights from the Cenozoic of Western Europe. Austrian Journal of Earth Sciences 2008; 101: 36-51.

[35] Mutti E., Tinterri R., Remacha E., Mavilla N., Angella S., Fava L. An Introduction to the Analysis of Ancient Turbidite Basins from an Outcrop Perspective. AAPG Course Note 39. Tulsa, Oklahoma: The American Association of Petroleum Geologists; 1999.

[36] Soh W., Tanaka T., Taira A. Geomorphology and sedimentary processes of a modern slope-type fandelta (Fujikawa fandelta), Suruga Trough, Japan. Sedimentary Geology 1995; 98: 79-95.

[37] Sinclair HD., Tomasso, M. Depositional evolution of confined turbidite basins. Journal of Sedimentary Research 2002; 72: 451-456.

[38] Itoh Y., Kusumoto, S., Inoue, T. Magnetic properties of siliceous marine sediments in Northern Hokkaido, Japan: a quantitative tectono-sedimentological study of basins along an active margin. Basin Research in press.

[39] Fukusawa H. Sedimentary mechanism of Neogene bedded siliceous rocks - on late Miocene Wakkanai Formation of northern Hokkaido, Japan. Journal of the Geological Society of Japan 1988; 94: 669-688. 
[40] Yamamoto M., Watanabe Y., Watanabe M. Paleoceanographic controls on the deposition of Neogene petroleum source rocks, NE Japan. Bulletin of the Geological Survey of Japan 1999; 50: 361-376.

[41] Bábek O., Mikuláš R., Zapletal J., Lehotský T. Combined tectonic-sediment supplydriven cycles in a Lower Carboniferous deep-marine foreland basin, Moravice Formation, Czech Republic. International journal of Earth Sciences 2004; 93: 241-261.

[42] Tinterri R., Muzzi Magalhaes P. Synsedimentary structural control on foredeep turbidites: An example from Miocene Marnoso-Arenacea Formation, Northern Apennines, Italy. Marine and Petroleum Geology 2011; 28: 629-657.

[43] Haq BU., Hardenbol J., Vail PR. Chronology of fluctuating sea levels since the Triassic. Science 1987; 235: 1156-1167.

[44] Allen PA., Allen JR. Basin Analysis: principles and applications, $2^{\text {nd }}$ edition. Oxford: Blackwell Science; 2005.

[45] Arita K., Ganzawa Y., Itaya, T. Tectonics and uplift process of the Hidaka Mountains, Hokkaido, Japan inferred from thermochronology. Bulletin of the Earthquake Research Institution of University Tokyo 2001; 76: 93-104.

[46] Kawakami G., Kawamura M. 2003, Reconsideration to the collision tectonics in central Hokkaido from the Miocene stratigraphy. Earth Science (Chikyu Kagaku) 2003; 57: 333-342. 